Olga Lundysheva,

Anna Turanskaya

\title{
Old Uyghur Fragments in the Serindia Collection: Provenance, Acquisition, Processing
}

DOI 10.17816/wmo48562

Abstract: The earliest findings of the Old Uyghur manuscripts and block prints were brought to Europe by the Russian expeditions. A number of the Old Uyghur fragments were found by Dmitrii Klementz in the course of the Turfan expedition in 1889-1890. These fragments, along with the manuscripts in other languages and scripts, were subsequently acquired by the Russian officials Nikolai Petrovskii and Nikolai Krotkov and the expeditions headed by Sergei Oldenburg (1909-1910; 1914-1915) and Sergei Malov (1909-1911; 1913-1914). They formed the Serindia (formerly known as Central Asian) Collection kept nowadays at the IOM, RAS. The major part of the Serindia Collection consists of the Old Uyghur fragments. Obtained by the expeditions to Eastern Turkestan, according to the customary tradition they were transferred to the Asiatic Museum. This paper presents the results of our recent study of the provenance, aquisition and processing history of the Old Uyghur manuscripts and block prints.

Keywords: Serindia Collection, Old Uyghur manuscripts, block prints, Asiatic Museum, manuscript collection, IOM, RAS

The major part (4730 items) of the Serindia Collection ${ }^{1}$ (priorly known as

(C) Olga Lundysheva, Institute of the Oriental Manuscripts, Russian Academy of Sciences, St. Petersburg (olgavecholga@gmail.com).

(C) Anna Turanskaya, Institute of the Oriental Manuscripts, Russian Academy of Sciences, St. Petersburg (turanskaya@mail.ru).

${ }^{1}$ The Serindia Collection contains 6,737 items in 13 languages: Sanskrit, Gandhari, Tocharian A and B (Kuchean), Khotan Saka, Sogdian, Middle Persian (Pahlavi), Old Uyghur, Chinese, Tibetan, Mongolian, Arabic, and Tumshuqese (Saka). The Collection includes 15 subcollections of different size and content, 13 of which bear the names of the acquirers. It was Segrei Fiodorovich Oldenburg who decided to systemize the materials this way. Originally these subcollections were kept under the following codes: B for Berezovskii; D - Diakov; Kl - Klementz; Koz - Kozlov; K - Kokhanovskii; Kol - Kolokolov; Kr - Krotkov; L - Lavrov; M, МА, Мтд - Malov; O - Oldenburg; P - Petrovskii; Rob - Roborovskii; Strel-D - Strelkov. Two other subcollections are: Uig that includes miscellaneous texts in Old 
Central Asian) ${ }^{2}$ appear to be book fragments in the so-called Old Turkic or Old Uyghur language, known by the Orkhon and Yenisey runiform inscriptions and manuscripts found in the eastern part of present-day Xinjiang Uyghur Autonomous Region and Gansu province of China. Obtained during expeditions to Eastern Turkestan organized by the Russian Geographical Society (RGS), Russian Archaeological Society (RAS) and Russian Committee for Middle and East Asia Exploration (RCMA) at the turn of the 20th c., book fragments in Old Uyghur script according to the customary tradition were transferred to the Asiatic Museum (AM). While some manuscripts were given to the AM almost at the same time they were brought to St. Petersburg, for others it took some time to be included into the Collection. ${ }^{3}$

The history of the formation and processing of the book fragments in Old Uyghur language remains unclear except for a few publications ${ }^{4}$ and contains a few gaps that will probably never be filled with complete confidence. However, some archival documents (inventory books, ${ }^{5}$ archival documents from the Archives of Orientalists, ${ }^{6}$ RCMA's transactions, private correspondence of the persons engaged in manuscripts acquisition, ${ }^{7}$ manuscript reg-

Uyghur script that were sorted into a separate unit due to unknown provenance, and Merv that consists solely of the manuscript discovered in 1965 at the Merv Oasis not far from BairamAli in Turkmenistan. 51 fragments do not belong to any subcollection as it is impossible to determine their provenance. One should note that the number of fragments kept under one call number differ significantly - from one to several dozens of fragments or even a hundred manuscript folios (e.g. SI $4498(\mathrm{M} / 1)$ ).

${ }^{2}$ It was Margarita I. Vorobiova-Desiatovskaia who decided to restore the original code 'SI' along with the name "Serindia" used by Sergei Oldenburg, in 2006. The new inventories of separately preserved at that time subcollections primarily aimed to unify the codes to facilitate search and make the Collection more easily available to the researchers.

${ }^{3}$ It was common for some scholars to keep manuscripts they were analyzing for their personal research. Thus, some manuscript fragments Wilhelm Radloff was researching were transferred to the AM only after his death.

${ }^{4}$ Dmitrieva 1969; TugusheVa 2008c; Lundysheva 2018.

${ }^{5}$ Seven inventory books kept in the Department of Manuscripts and Documents of the IOM, RAS include sixteen records concerning accessions of the Old Uyghur fragments. The major part of the records refers to accessions of printed books for the Academic Library of the IOM. The dates mentioned in these inventory books often do not coincide with real accession time.

${ }^{6}$ The information concerning Serindia Collection is preserved in the Archives of Orientalists, Fund 152, Inv. 1, 1a, 2. The documents contain information about manuscripts and books transferred to the AM and the Institute of Oriental Studies in Leningrad throughout their history.

${ }^{7}$ These documents are of great interest as they include more detailed description of the finds, provenance and archaeological excavations. Further research is required. 
ister lists ${ }^{8}$ ) can shed light on the general history of the formation of the Old Uyghur part of the Serindia Collection.

Old Uyghur fragments are distributed among ten subcollections. ${ }^{9}$ The history of formation (arranged in chronological order) and brief description of these subcollections is presented below.

\section{Roborovskii and Klementz subcollection (Rob., Rob.-Kle. and Uig.)}

According to the prominent Russian Turkologist, ${ }^{10}$ Director of the IOS, AS USSR from 1934 to 1937, Aleksander Nikolaevich Samoilovich, the first manuscript fragments written in Old Uyghur, that were transferred to the AM, were acquired during expeditions headed by Vsevolod Ivanovich Roborovskii and Dmitrii Aleksanderovich Klementz. ${ }^{11}$

Vsevolod I. Roborovskii (1856-1910), a participant of the third and fourth Przhevalskii's expeditions to Central Asia, headed the expedition organized by the RGS to Eastern Turkestan and North-Western China in 1983-1985. Although the expedition was not expected to be an archaeological one, Vsevolod I. Roborovskii managed to obtain a number of manuscript fragments in different scripts. According to his travel records, he purchased several scrolls from local people near Idiqutshari ruins, the former residence of the Kocho kingdom rulers. ${ }^{12}$ Old Uyghur manuscript fragments, that were among his

8 The earliest register list Arch. 69 named "Serindica. List of Uyghur collections of the AM. Uyghur manuscripts and fragments: Diakov, Krotkov, Malov, Berezovskii, Kokhanovskii, Roborovskii, Kozlov, Oldenburg subcollections" dates back to 1918. However, some records indicate that its final version had not been compiled until 1925. This register list is not complete as it does not include some manuscripts that are mentioned in register list from 1953. A register list from 1953 keeps records of all Old Uyghur fragments except for the items transferred to the IOS along with the Sergei Malov's documents after his death in 1957, and manuscript fragments that obtained call numbers after 2018 (after SI 6677).

${ }^{9}$ Old Uyghur fragments are not included into Klementz, Lavrov, Kolokolov, Strelkov subcollections.

10 The first attempt to systematize the AM's collections dates back to 1918-1920 when the researchers of the AM compiled and published a booklet "The Asiatic Museum of the Russian Academy of sciences. 1818-1918. Brief Summary". A. Samoilovich who was in charge of the Turkic manuscripts of the AM collection at that time.

11 Pamiatka 1920: 35.

12 Further details in RoBorovsKII 1900. 
finds in Idiqutshari and Toyuq-Mazar, were transferred to RGS and studied by Wilhelm Radloff (1837-1918). ${ }^{13}$

Later, Wilhelm Radloff described the Old Uyghur materials in his article "Altuigurische Sprachproben aus Turfan": "Im December 1897 wurden mir eine Anzahl beschriebener Papierfetzen übergeben, die die russischen Reisenden Roborovski und Kozlov aus Turfan nach St. Petersburg gebracht und der Kaiserlichen Russischen Geographischen Gesellschaft übergeben hatten. Eine genauere Prüfung dieser Schriftfragmente ergab folgendes Resultat: die meisten Schriftstücke enthielten türkische mit uigurischen Buchstaben geschriebene Texte, die nach den Schriftzügen und dem für dieselben verwendeten Papier zu urtheilen, in zwei scharf geschiedene Gruppen zu theilen waren. Die erste Gruppe war auf einer Seite eines sehr dünnen roh und ungleichmässig verarbeiteten Papieres geschrieben; die Schriftzüge waren in rundlichem Duktus mit dem Pinsel leicht hingeworfen und machten den Eindruck einer Schnellschrift, wie sie nur bei geschäftlichen Schriften verwendet werden konnte". ${ }^{14}$

These 'unintentional' finds by Vsevolod I. Roborovskii's expedition aroused so much interest that the Imperial Academy of Sciences sent a special expedition headed by Dmitrii A. Klementz to the region. ${ }^{15}$ A Russian explorer of Middle and Eastern Asia, archaeologist, and initiator of the pioneering Russian expeditions to the Tarim Basin for archaeological purposes, Dmitrii Klementz (1848-1914) visited Turfan in 1898. Although he personally deemed that manuscripts, acquired in Karakhoja during the expedition were insignificant, ${ }^{16}$ Wilhelm Radloff highly appreciated his finds. ${ }^{17}$ In 1899 he wrote:

\footnotetext{
13 OLDENBURG 1917: 219-220.

${ }^{14}$ In December, 1897, a number of paper scraps, that the Russian explorers [Vsevolod Ivanovich] Roborovskii and [Piotr Kuzmich] Kozlov had brought from Turfan to St. Petersburg and handed over to the Imperial Russian Geographical Society, were transferred to me. A closer examination of these fragments revealed the following: most of the materials contained Turkic texts written in Old Uyghur script. Judging by handwriting and paper, they can be divided into two groups. [Documents] from the first [group] are written on one side of a very thin, raw and uneven paper; the handwriting is of round ductus [written] by brush, [it] gives the impression of a shorthand that could only be used for official writing (RADLOFF 1899: 55).

${ }^{15}$ This fact is pointed out by Vsevolod I. Roborovskii in the preface to the publication of the expedition's materials (RoBOROVSKII 1900: 6).

${ }^{16}$ KLEMENTZ 1899: 47.

${ }^{17}$ For more detailed information see WHILFIELD 2008: 205.
} 
"Diese Schriftdenkmäler bestehen aus fünf Kategorien: 1) Abklatsche von an den Wänden einer Höhlenwohnung eingekratzten alttürkischen Inschriften; 2) Stücke vom Stuck der Klosterhöhlen, auf denen sich mit schwarzer oder braunrother Farbe geschriebene uigurische Inschriften befinden; 3) Fragmente buddhistischer religiöser Handschriften; 4) Fragmente von in Holzdruck ausgeführten buddhistischen Büchern; 5) Geschäftliche Schriftstücke in uigurischer Sprache. Die letzteren Schriftstücke haben für uns einen ganz besonderen Werth, weil sie einige abgeschlossene Dokumente enthalten, die bis auf wenige Stellen sich intakt erhalten haben und leicht entzifferbar sind. Ausser mehreren nur theilweise erhaltenen Stücken befinden sich zwei gut erhaltene Bescheinigungen, in denen die Verkäufer von Sklaven den Käufern die Bestätigung-des Besitzrechtes ausstellen". ${ }^{18}$

Tha fate of the above mentioned fragments is unclear. ${ }^{19}$ According to the Register list (Arch. 69) compiled in 1918, the Roborovskii subcollection of the AM included only three Old Uyghur manuscript fragments (SI 4871-4873 $(\operatorname{Rob} / 2-\operatorname{Rob} / 4)){ }^{20}$

It is well known that fragments of larger size (in particularly those that contained enough text for translation or even identification of the text title) were quite often kept by the researchers for their private use. ${ }^{21}$ This customary practice sometimes resulted in provenance loss. Thus, fragments stored

18 "The texts can be divided into five categories: 1) imprints of Old Turkic inscriptions carved on the cave walls; 2) stucco pieces of the cave temples with Old Uygur inscriptions written in black or brown-red color; 3) fragments of Buddhist religious manuscripts; 4) fragments of Buddhist block-printed books; 5) documents in Old Uyghur language. The latter are of special value as a few complete documents are intact and, apart from a few passages, easily decipherable. Among several fragments, preserved partially, there are two well-preserved documents, concerning the issues of slave trade" (RADLOFF 1899: 57).

19 The only record found in Arch. 4 from 1918 (record No. 486: "From Roborovskii materials: Old Uyghur manuscript") most probably refers to a Sogdian manuscript fragment kept nowadays under call number SI 2100 (Rob/1). Other records (No. 487-492) concerning Roborovskii subcollection list Chinese manuscripts. The later were probably integrated into the Dunhuang Collection of the IOM. The fragment of Roborovskii collection, a block printed fragment of Mañjuśrīnāmasamgīti was edited by Wilhelm Radloff under the call number Rb.1 (USp 1928: No. 59)

${ }^{20}$ According to Sergei F. Oldenburg, the list of manuscripts and artefacts acquired by Dmitrii A. Klementz had to be prepared by researchers of the AM. However, it was never published due to historical circumstances (OLDENBURG 1917: 227). The Klementz' subcollection preserved in the IOM consists of several Sanskrit manuscript fragments.

21 This is primarily proven by the fact that manuscript fragments were found in the private archives of the AM directors Wilhelm Radloff, Carl H. Salemann and Segrei F. Oldenburg after they passed away. 
by Wilhelm Radloff later obtained codes Kle.-Rob., and it is impossible to associate them with any of the explorers. Five fragments acquired by Dmitrii A. Klementz (published by Wilhelm Radloff ${ }^{22}$ and later by Sergei E. Malov in USp 1928: No. 55, 56, 57, 58, 59) are a rare exception. Several fragments that had been published in 1928 under call numbers Kle.-Rob. were later discovered in the subcollection of miscalleneous Old Uyghur materials 'Uig' and in the Photo Collection ${ }^{23}$ of the IOM.

Nowadays only two fragments of Mahāmāyūrī vidyārājñ̄i sūtra SI 4871$4872\left(\mathrm{Rob} / 2, \mathrm{Rob} / 3^{24}\right)$ and the Old Uyghur documents SI 4873 (Rob/4), SI 6544 (Uig/14), SI 6545 (Uig/15) and SI 6546 (Uig/16) could be assigned to the Roborovskii-Klementz subcollection. There is also a probability that three fragments of Buddhist texts SI 6540 (Uig/8, Uig/9), SI 6542 (Uig/11) and fragment of a document on the reverse side of the Chinese scroll SI 6539 (Uig/7) also belong to this subcollection.

\section{Kokhanovskii subcollection (K)}

On March 20, 1907, RGS transferred to the AM collections acquired from Aleksander Ivanovich Kokhanovskii, medical officer of the Consulate in Urumqi from 1904 to $1906 .{ }^{25}$ Aleksander I. Kokhanovskii ${ }^{26}$ led an expedition to Turfan in 1906-1907. ${ }^{27}$ As he purchased manuscript fragments from the local people their provenance is unknown.

The Kokhanovskii subcollection includes 34 items in Old Uyghur. The majority of fragments are of small size and include Buddhist texts SI 4904 (K/20), SI 4906-4908 (K/22-K/24), SI 4910-4913 (K/26-K/29), SI 4914$4918(\mathrm{~K} / 30)$, SI 5879, SI 5885, SI 5887-5890, SI 5892, SI 5915, SI 5995 (K/6), SI 6148, SI 6168, SI 6193, SI 6215, SI 6219, SI 6277, SI $6349(\mathrm{~K} / 7)$, SI 6593-6595, SI 6598 (no former call numbers) and one secular document SI 4909/1 (K/25a).

\footnotetext{
22 RADLOFF 1899.

${ }^{23}$ USp 1928: No. 48-52, 54-55, 57. Photocopies are preserved at the IOM Photo Collection, call number $Ф B-277$.

${ }^{24}$ It seems that originally these two fragments of the same manuscript were given call number Rob/3 (USp 1928: No. 60).

${ }^{25}$ According to transaction excerpt of the RGS meeting held on March 7, 1907 preserved in archival documents (Archives of Orientalists, Fund 152, Inv. 1, unit 47, f. 26).

26 Birth and death dates unknown.

${ }^{27}$ For the more detailed description of the expedition see PoPOVA 2011.
} 


\section{Berezovskii subcollection (B)}

Records of acquisition of the manuscript fragments collection obtained by Mikhail Mikhailovich Berezovskii's (1848-1912) expedition to Kucha in 1905-1907 were not found among IOM's archival materials. However, it is possible to suppose that the transfer took place in 1908-1909.

A prominent explorer of Central Asia, zoologist and biologist, Mikhail M. Berezovskii visited Subashi, Dolgur-akhur, Tadjit, Kumtura, Kucha, Kizil, and Kirish. Manuscript fragments acquired by Mikhail M. Berezovskii are of special value due to the precise indication of the places where they were found. Thus, it is known that Old Uyghur fragments were found in On-bash Ming-oi.

The Berezovskii subcollection includes four Buddhist fragments in calligraphic script SI 2951 (B/22), 23 fragments of unidentified texts in cursive script SI 2952-2954 (B/23), SI 2966 (B/30), scribal exercises SI 2964 (B/28) and three fragments with text written in slanting Brāhmī SI 2965 (B/29) (Sanskrit-Old Uyghur bilinguals).

\section{Diakov subcollection (D)}

It is known that Aleksei Alekseevich Diakov (1876?), secretary of the Consulate and later Consul in Kuldja (1906-1912) and Urumqi (1913-1915), visited the site of Astana located in Turfan oasis on August 15-20, 1908. There he managed to acquire a large fragment of a block print, two manuscript scrolls and 81 manuscript fragments, 70 of which appeared to be in Old Uyghur. ${ }^{28}$ These materials were transferred by the RCMA to the AM in $1909 .{ }^{29}$

The Old Uyghur part of the subcollection includes a coloured amulet with dhāraṇī text SI 3123 (D/5), a scroll fragment of Avalokiteśvara sūtra (Kuanši-im Pusar) SI 3158 (D/2), almost complete sroll ${ }^{30}$ of Manichean confession of sins (X uastvanift) SI 3159 (D/1), 14 folios of the block print edition of Avatamsaka sūtra SI 4842 (D/3), 48 manuscript fragments of Suvarnaprabhāsottama sūtra (Altun Yaruk) SI 4843 (D/4) and other unidentified Buddhist texts

\footnotetext{
28 The major part of articles mentioning Aleksei A. Diakov state that he managed to obtain only 28 manuscript fragments (KLYASHTORNY 2008: 53; BuKHARIN 2013: 441).

${ }^{29}$ Arch. 3 from 1909, record No. 1976. According to archival document (Archives of Orientalists, Fund 152, Inv. 1, unit 50, f. 131) these materials were transferred to the AM on December 3, 1909.

${ }^{30}$ First 15 lines of the text are lost.
} 
SI 4844 (D/6), SI 4846 (D/10), SI 4845 (D/7), SI 4850 (D/14-1), SI 4854 (D/16), SI 4857 (D/19), SI 4860 (D/23), SI 4861 (D/24a), SI 4862 (D/24b), SI $4863(\mathrm{D} / 25)$ and secular documents SI 4847 (D/11),

SI 4848 (D/12), SI 4849 (D/13), SI 4851 (D/14-2), SI 4852 ( D/14-3), SI 4853 (D/15), SI 4855 (D/17), SI 4856 (D/18), SI 4858 (D/20, D/21), SI $4859(\mathrm{D} / 22)$.

\section{Krotkov subcollection (Kr)}

The majority of Old Uyghur manuscript and block print fragments in the Serindia Collection belong to the subcollection granted by Nikolai Nikolaevich Krotkov (1869-1919), Consul in Urumqi, and later, secretary of the Consulate in Jilin, Qiqikar and Kuldja. Being an expert in Eastern Turkestan history and culture, Nikolai N. Krotkov not only purchased numerous manuscript fragments from the local people, but also carried out archaeological excavations in the vicinities of Urumqi, Toyuq, Yar-Khoto and Gaochang. ${ }^{31}$ The materials that he managed to obtain were transferred to the RCMA, and later to the AM, in four separate parcels.

The so-called 'first Krotkov collection' 32 was brought to St. Petersburg in 1907 and became part of the AM holdings in 1908. ${ }^{33}$ Due to historical circumstances, call numbers of manuscript fragments in Old Uyghur and Sogdian were changed several times. ${ }^{34}$ Finally, this part of the collection obtained call numbers $\mathrm{Kr} I / 1-\mathrm{Kr} I / 487, \mathrm{Kr} I I / 1-1-\mathrm{Kr} I \mathrm{I} / 1-819, \mathrm{Kr} I I / 2-1-$ $\mathrm{Kr} I I / 2-669, \mathrm{Kr} I I / 3-1-\mathrm{Kr} I I / 3-371, \mathrm{Kr} I I / 4-1-\mathrm{Kr} I \mathrm{I} / 4-120, \mathrm{Kr} I I / 5-\mathrm{Kr} \mathrm{II} / 50$,

\footnotetext{
${ }^{31} \mathrm{He}$ also paid a special attention to the materials in the Manchu and Xibo languages (PANG 2018: 483-486).

32 The paper case with this title is preserved among the archival materials (Archives of Orientalists, Arch. 69).

${ }^{33}$ According to the RCMA meeting records, dated November 10, 1907, and May 10, 1908, N. Krotkov brought the materials and presented them to the Committee in person. C. Salemann, director of the AM at that time, highly evaluated the collection and persuaded the Committee to purchase it for an enormous sum of 5000 rubles, 4,000 of which were paid from Turfan excavation funds. According to the archival materials, on December 11, 1908, RMCA transferred to the AM 71 manuscript fragments from N. Krotkov's collection, 23 of which are in Old Uyghur (Archives of Orientalists, Fund 152, Inv. 1, unit 48, f. 102).

${ }^{34} \mathrm{This}$ is obvious from the call numbers mentioned in the inventory books (e.g. $\mathrm{Kr} / \mathrm{VII}-\mathrm{Kr}$ / $\mathrm{XL}$ etc.). Manuscript fragments in Brāhmī script were most probably united into a separate unit as they bear primarily given call numbers.
} 
Kr III/1-Kr III/40, Kr IV/1-Kr IV/194, Kr. Дon/1-6 (for Old Uyghur fragments, 11 of which are written on the reverse side of Chinese scrolls), Kr IV/195-Kr IV/223 (for Sogdian fragments).

The second part of the collection that had been contributed by Nikolai N. Krotkov to the RCMA was brought to St. Petersburg in 1909 by a member of the first Russian Turkestan Expedition headed by Segrei F. Oldenburg, Vladimir Kamenskii, who had to return from the Expedition half-way due to his illness. ${ }^{35}$ According to the records found in the IOM inventory books, manuscript fragments were transferred to the AM in autumn $1909^{36}$ and later were given call numbers $2 \mathrm{Kr} / 1-2 \mathrm{Kr} / 90$. In addition, on May 15, 1910, thirteen folios of Old Uyghur 'concertina' book SI 5817-5818 (3 Kr/a-c) were sent by Nikolai N. Krotkov in a separate parcel to Wilhelm Radloff. ${ }^{37}$

The RCMA received the third part of the Krotkov collection on March 28, 1911. These materials could be considered to be of special value as their provenance is known. According to the preserved archival documents (Archives of Orientalists, Fund 152, Inv. 1, unit 52, f. 52, RCMA meeting of March 31, 1911), the RCMA received a parcel that included two Tibetan manuscripts, two Tibetan and two Chinese manuscripts from Dunhuang, a package with Old Uyghur and Chinese manuscript fragments found in Yar-khoto ruins, two - from Kara-Khodja, and one package with manuscript fragments acquired during excavations in Toyuq.

In summer 1911, Nikolai N. Krotkov brought the last, forth part of his collection to St. Petersburg and passed it to the RCMA. It seems probable that materials included into the second and third parcels were sorted by Nikolai N. Krotkov himself. One may assume that he primarily selected manuscript fragments of larger size and those that seemed more interesting to be send to RCMA. Thus, fragments from the last part of his collection can be joined with those that were sent earlier. ${ }^{38}$

Records concerning the third and the last parts of Nikolai. Krotkov collection are listed in the Inventory book from $1918 .{ }^{39}$ One may suppose that these

${ }^{35}$ Record of the RCMA meeting dated September 22, 1909.

${ }^{36}$ Arch. 3, 1909, record No. 799.

${ }^{37}$ This is affirmed by a private letter sent by Nikolai N. Krotkov to Sergei F. Oldenburg, preserved in SPbB ARAS (Fund 208, Inv. 30, unit 305, ff. 3435).

${ }^{38}$ This assumption is rather plausible as joint fragments were found. For example, SI 3791 (2 Kr/17), SI $5726(2 \mathrm{Kr} / 27)$ and SI $1783(\mathrm{Kr}$ IV/256).

${ }^{39}$ The register list (Arch. 4, 1917, record No. 432) mentions only Tibetan block print folio, two Tibetan manuscript fragments, 16 fragments in Brāhmī script, and Chinese and Mongolian fragments. 
materials were transferred between 1911 and 1917 by Wilhelm Radloff, who was engaged in sorting the Old Uyghur collection of Nikolai N. Krotkov, or after his death.

According to the archival materials and pencil notes on the margins, Wilhelm Radloff selected Old Uyghur fragments of larger size and gave them call numbers $3 \mathrm{Kr} / 1-3 \mathrm{Kr} / 41$, 4 a $\mathrm{Kr} / 1-4 a \mathrm{Kr} / 76$, $4 b \mathrm{Kr} / 1-4 b \mathrm{Kr} / 23$. It is known that some manuscript fragments (at least with call numbers 3 $\mathrm{Kr} / 26-3 \mathrm{Kr} / 50^{40}$ ) from this part of the collection had never been transferred to the AM (preserved in the Photo Collection of the IOM, RAS). The last part of the collection was sorted by the researchers of the AM after 1918 and obtained call numbers $4 b \mathrm{Kr} / 24-4 b \mathrm{Kr} / 236, \mathrm{Kr} \mathrm{IV} / 224-\mathrm{Kr} \mathrm{IV} / 879 .{ }^{41}$

Krotkov subcollection comprises 4454 Old Uyghur manuscript and block print fragments. More than 800 fragments are written on the reverse of Chinese scrolls, while 28 on the reverse of Sogdian manuscripts. SI 6603-SI 6613 include 530 Old Uyghur fragments of a rather small size sealed in $11 \mathrm{Me}-$ linex lists. Being the largest subcollection of Old Uyghur book fragments it includes Mahāyāna and non-Mahāyāna texts, Chinese apocrypha and secular documents. $^{42}$

\section{Oldenburg subcollection (O)}

Sergei Fiodorovich Oldenburg (1863-1934), a prominent Russian Orientalist, director of the AM from 1916 to 1934, obtained numerous manuscript

${ }^{40}$ Photos of the manuscript fragments with call numbers $3 \mathrm{Kr} / 26-3 \mathrm{Kr} / 50$ were transferred to the AM by Sergei E. Malov in 1928, after publication of USp. Manuscript fragments preserved nowadays in the Serindia Collection under the same former call numbers do not refer to the fragments edited by Wilhelm Radloff and published by Sergei E. Malov. These call numbers were assigned to Sogdian fragments after the World War II during inventory procedures. The photos of the Old Uyghur fragments considered to be lost remained in the IOM Photo Collection under call numbers ФB-77, ФВ-277.

${ }^{41}$ The codes $4 \mathrm{~b} \mathrm{Kr}$ and Kr IV were also given to Chinese, Sanskrit, Tocharian A and B, Sogdian, Middle Persian and Old Uyghur fragments from the second and third parts of the collection (for some reason Wilhelm Radloff had not given them any call number).

${ }^{42}$ Another document in Old Uyghur is found on the verso of the unit G 120 kept at the Mongolian Collection of the IOM. The circumstances that resulted in its transfer to the Mongolian Collection are unknown. The register list of 1918 mentions the empty envelope with the note 'Kr. V 1-2. Taken by Kotwicz to the Mongolian Department'. Thus, one may suppose that the fragment with Mongolian text on recto was taken by a prominent Russian Mongolist, Władysław Kotwicz (1872-1944) for work, and was subsequently transferred to the Mongolian Collection.

One may assume that some Old Uyghur fragments obtained by Nikolai N. Krotkov were incorporated into the Dunhuang Collection, this assumption requires further research. 
fragments written in different Central Asian scripts during the First and Second Russian Turkestan Expeditions (1909-1910 and 1914-1915). The fragments acquired by Sergei F. Oldenburg are included into subcollection that bears his name.

Sergei F. Oldenburg's First Russian Turkestan Expedition carried out excavations at the northern oases of Eastern Turkestan, i.e. Karashar, Turfan and Kucha. As a result, a dozen surface and cave Buddhist temples were investigated, ${ }^{43}$ and several hundred manuscript fragments were brought to St. Petersburg. Although the fragments (mainly found in the cities of Bäzäklik, Idiqutshari, Toyuq-Mazar and Chyktym located in Turfan area) were considered to be of special value, Sergei F. Oldenburg was deeply frustrated with the small amount and preservation state of his finds. ${ }^{44}$

During his second expedition Sergei F. Oldenburg surveyed the Mogao Caves in Dunhuang and revisited some of the sites in Turfan. He found a large number of artefacts and manuscript fragments (nearly 20000 items) in Dunhuang, and also purchased about 300 scrolls from the local people. These materials, including Old Uyghur fragments, are incorporated into a separate Dunhuang Collection of the IOM, RAS.

Nowadays the Oldenburg subcollection includes 102 items in Old Uyghur: SI 3114/1 (O/66), SI 3116/3 (O/7c), SI 3161 (O/49a-d), SI $3162(\mathrm{O} / 50)$, SI $4586(\mathrm{O} / 2-6)$, SI $4603(\mathrm{O} / 3-9,1-\mathrm{O} / 3-9,2)-S I 4605(\mathrm{O} / 3-9,4)$, SI 4609 (O/4-4), SI 4620 (O/5-10,1), SI $4621(\mathrm{O} / 5-10,2)$, SI $4624(\mathrm{O} / 6-2)$, SI 4664 (O/15-1)-SI 4667 (O/15-4), SI 4671 (O/15-8), SI 4679 (O/16-4в)-SI 4685 (O/16-9), SI 4686 (O/29)-SI 4688 (O/31), SI 4691 (O/36)-SI 4693 (O/38), SI 4695 (O/41)-4713 (O/48a-d), SI 4614 (O/51), SI $4716(/ 54)-S I 4717$ (O/55), SI 4718 (O/73), SI 4720 (O/76), SI 4724 (O/26), SI 4725 (O/56)SI 4732 (O/63), SI 4735 (O/70), SI 4738 (O/77a)-SI 4765 (O/105), SI 4768

${ }^{43}$ More details in Oldenburg 1914. The materials acquired by Sergei F. Oldenburg in the course of his expeditions nowadays are preserved in the IOM, RAS, the State Hermitage Museum and the Russian Museum of Ethnography. Particularly worthy to note are vast archives of the Russian Turkestan Expeditions, kept in the State Hermitage Museum, the St. Petersburg Branch of the Archives of the Russian Academy of Sciences and the Archives of Orientalists kept in the Institute of Oriental Manuscripts.

44 A prominent Russian Indologist, Theodor Stcherbatsky (1866-1942) summarized the resultsof Sergei F. Oldenburg the following way: "As a result, when the expedition led by S.F. [Oldenburg] set out, that country had already been visited by a large number of other expeditions that had literally plundered the area, archaeologically speaking. Having arrived in their wake, the Russian expedition could but establish the fact and return home practically empty-handed" (STCHERBATSKY 1935: 26) 
(O/109), SI $4776(\mathrm{O} / 113 \mathrm{a}-\mathrm{b})-S I 4777(\mathrm{O} / 113 \mathrm{c})$, SI $4820(\mathrm{O} / 39)-S I 4823$ (O/40c), SI 4824 (O/48d), SI 4836 (O/198), SI 6560. Moreover, fragments preserved separately and registered as "Toyuq-Mazar 1909" most likely refer to this subcollection, and are under research nowadays. By now 60 fragments in Old Uyghur, 35 of which are written on the reverse side of Chinese scrolls, have obtained call numbers SI 6677, SI 6678, SI 6619-6676. The majority of fragments in the subcollection are too small to identify the text. The larger of them contain Buddhist texts, though several unique secular documents ( $S I$ 4716 (O/54), SI 4717 (O/55), SI 4718 (O/73), SI 4735 (O/70), SI 4820 (O/39), SI $4747(\mathrm{O} / 89))$ can be found.

Moreover, a few fragments are considered to be lost nowadays. Thus, at least four fragments (not found by now in the collection of the IOM) were published as $\mathrm{O} / 1^{45}$ and $\mathrm{O} / 2 .{ }^{46}$

\section{Petrovskii subcollection (P)}

Nikolai Fiodorovich Petrovskii (1837-1908) was one of the Russian diplomats who contributed greatly to academic research of the Eastern Turkestan region. Appointed as a Russian Consul in Kashgar in 1882, he collected manuscripts and art objects, buying them from the local people of Kucha, Korla, and Aksu and carrying out archaeological excavations, primarily in Kucha. Between the years 1892 and 1893, Nikolai F. Petrovskii forwarded to Sergei F. Oldenburg over 100 folios and fragments of manuscripts that he purchased from the inhabitants of Turfan. In 1905, he donated the entire Eastern Turkestan collection of the manuscripts to the RCMA that were later transferred to the AM.

${ }^{45}$ A small fragment of a book written in Old Turkic runic script (a folio with six incomplete lines) was bought by Sergei F. Oldenburg in Khara-Khodja in 1909, from a local peasant who had dug up a shabby piece of paper at the site of Idiqutshari. The text, which was published by Wilhelm Radloff, is too fragmentary to be identified (RADLOFF 1910: 1025-1036). A document concerning adoption with call number $\mathrm{O} / 1$ was edited by Wilhelm Radloff and published by Sergei E. Malov (USp 1928: No. 98). Photocopy is preserved in the IOM Photo Collection.

${ }^{46}$ A fragment of Garbaparimočana was edited in USp 1928: No. 102. A photocopy of document marked as $\mathrm{O} / 2$ is preserved in the IOM photo collection. Moreover, archival materials mention the Sogdian manuscript with the same call number: (Arch. 4, 1919, record No. 1178) "Ms. buddh. sogd. O2. Sogdian manuscript brought by Sergei F. Oldenburg from Dunhuang. 1 f.". Manuscript fragments preserved with former call numbers $\mathrm{O} / 1$ and $\mathrm{O} / 2$ are in Sanskrit. These call numbers were given during the inventory procedures after World War II. 
The Petrovskii subcollection includes 582 items, four of them are in Old Uyghur. These are two fragments in cursive script SI 1924 (P/132), SI 3629 $(\mathrm{P} / 1253)$ and two documents written on wooden tablets SI 3660 (Р/137д), SI $3671(\mathrm{P} / 1406)$.

\section{Malov subcollection (M, MA)}

In 1909-1911 and 1913-1914, Sergei Efimovich Malov (1880-1957) made journeys to Eastern Turkestan (Chuguchak (Tacheng), Urumqi, Turfan, KharaKhodja, Hami, Suzhou) and Central China (Lop Nor, Aksu, Yarkend, Khotan and Kashgar). His expeditions pursued rather ethnographical and linguistical ${ }^{47}$ than archaeological goals. Despite this fact, Sergei E. Malov acquired a number of manuscript fragments in Old Uyghur and other languages, i.e. Khotan Saka, Sanskrit, Mongolian, ${ }^{48}$ Tibetan, ${ }^{49}$ and Chinese.

The major part of his collection was customarily granted by the RCMA to the AM. Some fragments found in the Museum of Anthropology and Ethnography in 1920 s were transferred later, in $1925 .^{50}$

Fragments of Sitātapatrā dhāraṇī block print SI 4502 (M/5) and two documents from Turfan SI 4503 (M/5), SI 4504 (M/6) purchased by Sergei Malov during his second expedition to China were personally passed by him to the IOS in 1952. ${ }^{51}$ Several fragments were transmitted to the IOS after Malov's death. They were found in his private archive and obtained call numbers MA/... during inventory procedures in 1994.

${ }^{47}$ The main aim of Malov's journeys was to study the language and everyday life of the local Turkic peoples, i.e. the Uyghur, the Yellow Uyghur, the Lop Nor and the Salar peoples. Sergei E. Malov also acquired abundant ethnographic material from Turkic nationalities native to Eastern Turkestan (transferred to the Peter the Great Museum of Anthropology and Ethnography (the Kunstkamera) in 1925). Moreover, he provided a large number of photographs, part of which are kept nowadays in the IOM, RAS.

${ }^{48}$ Mongolian manuscripts acquired by Sergei E. Malov are preserved separately in Mongolian Collection of the IOM, RAS.

49 Tibetan collection acquired by Sergei E. Malov is of special value and includes early Tibetan wooden documents from Miran fortress.

${ }^{50}$ According to archival documents (Archives of Orientalists, Fund 152, Inv. 1a, unit 86, f. 2), on March 20, 1925, the Museum of Ethnography and Anthropology transferred to the AM manuscript fragments acquired by Sergei E. Malov during his journey to Eastern Turkestan in 1914 and manuscript fragments found among private documents of Wilhelm Radloff after his death.

${ }^{51}$ A note written by Sergei E. Malov is attached to the items. 
Malov subcollection includes 24 items in Old Uyghur language kept under call numbers SI 4498-SI 4504 (M/1-M/7), SI 4559-SI 4575 (MA/1-MA/11). His major finds were the most extant text of the Old Turkic version of the Suvarnaprabhāsottama sūtra (Altun Yaruk) SI 4498 (M/1), SI 4500 (M/3) and accompanying text Buyan ävirmäk SI $4499(\mathrm{M} / 2)^{52}$ discovered during his first expedition in the Buddhist temple located in the village of Wenshigu near Suzhou, in Gansu province.

\section{Kozlov subcollection (Koz)}

In 1907-1909, a large number of manuscripts and woodblock prints in various languages were discovered by a Russian traveller and explorer Piotr Kuzmich Kozlov (1863-1935) at the ruins of Khara-Khoto, a fortified town of the Tangut state (1038-1227). The unearthed texts included numerous Tangut manuscripts and block prints, in addition to those written in Chinese, Tibetan and Mongolian. One Old Uyghur fragment SI 4841 (Koz/5) is found in his subcollection. ${ }^{53}$

\section{Miscalleneous subcollection (Uig)}

Subcollection of miscalleneous manuscript fragments marked as ' $U i g$ ' includes 27 items SI 3156 (Uig/3), SI 3157 (Uig/12), SI 5066 (Uig/19), SI 6534-6557 (Uig/1-Uig/2, Uig/4-Uig/11, Uig/13-Uig/18). It is most probable that this subcollection was formed to unite manuscript fragments with unknown provenance or separate fragments brought by other researchers.

Thus, call numbers Uig/1 and Uig/2 (now SI 6534 and SI 6535 correspondingly) were assigned to Chagatai official documents of the 15th $\mathrm{c}$. written in Old Uyghur script that were granted to Vasilii Vladimirovich Barthold in 1902 in Margilon (Fergana Region in eastern Uzbekistan). Due to unknown reasons Manichean fragments of small size and fragments of miniatures and drawings made on textile and paper SI 5066 (Uig/19),

52 The record concerning these manuscripts is preserved in: Arch. 3, 1913, record No. 1545.

53 On the verso of the manuscript fragment "From P.K. Kozlov finds in Khara-Khoto" is written. Archival materials (Arch. 4, 1919, record No. 275) erroneously note that this fragment along with other fragments in Arabic script were acquired by Sergei F. Oldenburg in 1910. 
SI 6547-SI 6553 (Uig/17), SI 6554-SI 6557 (Uig/18) were also included in this subcollection. History of their acquisition remains obscure.

The provenance of the remaining items now can be determined with sufficient certainty. As it was mentioned above, SI 6544 (Uig/14), SI 6545 (Uig/15), SI 6545 (Uig/16) with confidence and SI 6539 (Uig/7), SI 6540 (Uig/8, Uig/9), SI 6542 (Uig/11) with some uncertainty belong to Roborovskii and Klementz subcollections respectively.

Untill recenty the details of acquisition of unique manuscripts of the $B i$ ography of Xuanzang SI 3156 (Uig/3), SI 6538 (Uig/6)) and Abitaki sütra SI 6536-6537 (Uig/4-Uig/5) were unknown. However, analyzing the archival documents it became obvious that these Old Uyghur manuscript fragments were sent to the IOS in 1932 by the supervisor of the Second Oriental department of the People's Commissariat for Foreign Affairs, Boris I. Kozlovskii (1899-1975).

\section{Processing the Old Uyghur fragments}

It should be pointed out that the collections of Old Uyghur manuscript and block print fragments were built up rather unsystematically, according to the chronological sequence of the new arrivals. The very first attempt to systematize the collection, is an inventory of the so-called "first Krotkov collection" (Kr I) compiled by the AM's director Carl Salemann. ${ }^{54}$ It was a preliminary attempt, where the quantity of the fragments was arranged in a table in order to calculate a total number of items. Carl H. Salemann used only criteria of language and type (ms./xyl.: manuscript or block print). ${ }^{55}$ Another attempt to encompass all the Old Uyghur collections that were transferred to the AM by

${ }^{54}$ Salemann 1908.

${ }^{55}$ As it was written later on the title page: "The numbering of this inventory was subsequently replaced by another. No concordance. Now see the Krotkov collection No. 1". Together with this inventory one can find:

1) list, enumerating contents of the cases and folders of the first Krotkov collection, also written by Carl Salemann (Serindica: lists 1918: 19-21);

2) list of the second Krotkov collection in manuscript and typescript form, as it was presented at the meeting of the Historical and Philological Department of the Academy on September 16, and November 4(17), 1909, and list of the same collection's items received from Wilhelm Radloff on October 31 (Serindica: lists 1918: 22-23, 26);

3 ) other lists related to the second Krotkov collection (Serindica: lists 1918: 4-5, 16-17);

4) list of the items found by Mikhail M. Berezovskii at Kizil-Min-Öy, Kizil-Karga and Tadjik (Serindica: lists 1918: 2-3). 
1930, most probable was compiled by Sergei F. Oldenburg. ${ }^{56}$ The first complete inventory list of Old Uyghur book fragments was made only in 1952 by the researcher of the IOS, Liudmila Vasiliievna Dmitrieva (1924-1997) with support of Sergei E. Malov.

The AM (later - IOS) where the items were stored, conducted inventory, cataloguing and academic research. The process continues to present day. Foremostly the absence of the catalogue ${ }^{57}$ of the Old Uyghur fragments (due to their fragmentary nature) makes the situation more complicated and hinders the research process. According to the archival documents dated January, 1917, Sergei F. Oldenburg, Director of the AM at that time, had the intention to request Sergei E. Malov to sort and make a catalogue of the acquired fragments. ${ }^{58}$ However, due to historical reasons, these intentions were never translated into reality.

Nevertheless, a large part of the texts was published already at the beginning of the first decade of the 20th c. due to the combined efforts of brilliant Turcologists Wilhelm Radloff and Sergei E. Malov. They were able to edit and publish the more 'voluminous' fragments - Xuāstvānīft, Manichean confession of sins,${ }^{59}$ an Uyghur version of Dišastvustik (Skt. Dišāsauvāstikasūtra), ${ }^{60}$ Avalokiteśvara sütra, or chapter 25 of the Chinese translation of Saddharmapuṇdarika sūtra (Kuanši-im Pusar), ${ }^{61}$ Suvarnaprabhāsottama Sütra known as Altun Yaruk, ${ }^{62}$ and numerous fragments of Buddhist texts and secular documents. ${ }^{63}$

After Wilhelm Radloff's death, there was no specialist in Old Uyghur language at the AM. Sergei E. Malov was never affiliated to the AM or IOS, although he provided assistance in inventorying and identification of fragments. This is proved by his numerous handwritten notes, found among the manuscripts of the Serindia Collection and mentioned in L'udmila V. Dmitrieva's

\footnotetext{
${ }^{56}$ Serindica: Lists 1918: 6-15. The list mentions 3588 fragments.

${ }^{57}$ This also refers to the collections of texts in other languages and scripts. By now, only the catalogue of Sogdian fragments by Asiia N. Ragoza is available (RAGOZA 1980).

58 The Department of History and Philology of the Imperial Academy of Sciences meeting record dated January 11, 1917, preserved in the archival materials (Archives of Orientalists, Fund 152, Inv. 1, unit 60, f. 10) proves it.

${ }^{59}$ RADLOFF 1909.

${ }^{60}$ RADLOFF 1910.

${ }^{61}$ RADLOFF 1911.

62 Radloff, Malov 1930.

${ }^{63}$ USp 1928; MaLov 1927, 1930, 1932, 1951.
} 
article concerning Old Uyghur texts kept at the IOS. ${ }^{64}$ By Sergei E. Malov's efforts the photo copies used in the USp edition were transferred from the publishing house to the Institute.

The research of the Old Uyghur materials was resumed only in the 1960s, but the lack of already published foreign literature and few contacts with foreign colleagues made the majority of research results less promising. Thus, Liudmila V. Dmitrieva (1924-1997) re-edited and published the Xuāstvānīft. ${ }^{65}$ In turn, Lilia Yu. Tugusheva (1932-2020) published fragments of the 5th, 6th, 8th and 10th chapters of the Biography of Xuanzang, ${ }^{66}$ a number of Buddhist texts ${ }^{67}$ and secular documents, including contracts, private and official letters etc. ${ }^{68}$ Later she edited the Uyghur version of the Daśakarmapathāvadānamāla $\bar{a}^{69}$ (in cooperation with Masahiro Shōgaito), the Abitaki sütra ('Sūtra of the White Lotus Society'), ${ }^{70}$ and published reeditions of the Xuāstvānifft $t^{71}$ and secular documents of the 10th-14th cc. ${ }^{72}$

The contribution to the study of the Old Uyghur fragments kept in the IOM made by foreign specialists could not be overestimated. Due to the efforts of the European colleagues Peter Zieme, György Kara, Simone-Christiane Raschmann, Abdurishid Yakup and the Japanese colleagues, Masahiro Shōgaito, Juten Oda, Dai Matsui, Takao Moriyasu, Hiroshi Umemura, Kōichi Kitsudō, numerous fragments of Buddhist texts and secular documents were identified and published. ${ }^{73}$

Nowadays the processing and further research of the Old Uyghur part of Serindia Collection is continued by the researchers of the IOM, RAS. Their main aim is to present to academic community a "Catalogue of the Old

${ }^{64}$ DMitrieva 1969: 222, note 1.

${ }^{65}$ DMitrieva 1963.

${ }^{66}$ TugusheVA 1972; Tugusheva 1991. According to the archival documents (Fund 152, Inv. 1a, unit 279, ff. 4-5), the Biography of Xuanzang and Abitaki sütra were identified by Sergei E. Malov soon after they were transferred to the IOS in 1932.

${ }^{67}$ Tugusheva 1970; Tugusheva 1975; Tugusheva 1978; Tugusheva 2004; Tugusheva 2007.

${ }^{68}$ Tugusheva 1971; Tugusheva 1996a; Tugusheva $1996 \mathrm{~b}$.

${ }^{69}$ Shōgaito et al., 1998.

70 Tugusheva 2008b.

71 Tugusheva 2008a.

72 Tugusheva 2013. The majority of texts were edited in USp 1928, SUK 1993, etc.

${ }^{73}$ The list of edited and published fragments is too extensive to be incorporated into the present article, and it will be included into the forthcoming first volume of the "Catalogue of the Old Uyghur manuscripts and blockprints in the Serindia Collection of the Institute of Oriental Manuscripts of the Russian Academy of Sciences" (ed. by Peter Zieme). 
Uyghur manuscripts and blockprints in the Serindia Collection of the Institute of Oriental Manuscripts of the Russian Academy of Sciences". The catalogue was compiled by the researchers of the IOM, RAS in cooperation with the Tōyō Bunko (The Oriental Library, Tokyo) will give a new impetus to further projects of editing the Old Uyghur texts of the IOM, RAS. ${ }^{74}$

\author{
Abbreviations \\ AM: Asiatic Museum \\ IOM, RAS: Institute of Oriental Manuscript of the Russian Academy of Sciences \\ IRGS: Imperial Russian Geographical Society \\ RAS: Russian Archaeological Society \\ RCMA: Russian Committee for Middle and East Asia Exploration \\ RGS: Russian Geographical Society \\ SPbB ARAS: St. Petersburg Branch of Archive of Russian Academy of sciences \\ USp: Uigurische Sprachdenkmäler \\ SUK: Sammlung Uigurischer Kontrakte \\ ФB-77: IOM, RAS Photo Collection access number \\ ФB-277: IOM, RAS Photo Collection access number
}

\title{
References:
}

Bukharin, Mikhail D. 2013: "Pis'ma A.A. Diakova k S.F. Ol'denburgu iz sobraniia SPF ARAN" [Letters of A.A. Diakov to S.F. Oldenburg from the Collection of St. Petersburg Branch of the Russian Academy of Sciences]. Vestnik istorii, literatury, iskusstva [Journal of History, Literature, Arts] 9 (2013). Moscow: Nauka: 440-448.

DMitrievA, Liudmila V. 1963: "Khuastuanift (Vvedenie, tekst, perevod)" [Xuastvanift (Introduction, text, translation)]. Tiurkologicheskie issledovaniia [Turkological Studies]. Moscow; Leningrad: Izdatel'stvo Akademii nauk SSSR: 214-232.

DMitRIEVA, Liudmila V. 1969: "Drevneuigurskie materialy (uigurskim pis'mom) v Institute vostokovedeniia Akademii nauk SSSR" [Old Uyghur materials (in Old Uyghur script) in the Institute of Oriental Studies of the Academy of Sciences of the USSR]. Strany i narody Vostoka, Vypusk VII. Geografiia, etnografiia, istoriia [Countries and Peoples of the East. Vol. 7. Geography, ethnography, history]. Moscow: Nauka: 222-228.

KlementZ, Dmitrii 1899: Turfan und seine alterhümer. Nachrichten über die von der Kaizerlichen Akademie der Wissenschaften zu St. Petersburg im Jahre 1898 ausgerüstete Expedition nach Turfan. Hf. 1. St. Petersburg: 1-53.

${ }^{74}$ Although a preliminary list of the Old Uyghur fragments was published in 2002 under the title "A Provisional Catalogue of the Microfilms of Uigur, Sogdian and Manichaean Manuscripts belonging to the St. Petersburg Branch of the Institute of Oriental Studies, Russian Academy of Sciences brought to the Tōyō Bunko" by Hiroshi Umemura, Masahiro Shōgaito, Yutaka Yoshida and Abdurishid Yakup, this work did not find the necessary acceptance due to its limited distribution. The fisrt volume of edited and published in the last hundred years Old Uyghur fragments will be released in 2021. 
KLyashtorny, Sergei G. 2008: Old Turkic Monuments of Runic Writing from Eastern Turkestan. In: Russian Expeditions to Central Asia at the Turn of the 20th Century. Collected articles. Ed. by Irina F. Popova. St. Petersburg: Slavia Publishers: 50-64.

LundysheVA, Olga V. 2018: Serindiiskii fond [Serindia Collection]. Aziatskii Muzei-Institut vostochnikh rukopisei. Putevoditel' [Asiatic Museum - Institute of Oriental Manuscripts, RAS. Guidebook]. Moskva: Izdatel'stvo vostochnoi literatury: 270-293.

Malov, Sergei E. 1927: Dva uigurskikh dokumenta [Two Uyghur documents]. Raboty Vostochnogo fakul'teta Sredne-Aziatskogo Universiteta [Issues of the Faculty of Oriental Studies of the Middle Asian University]. Tashkhent: 387-394.

MALOV, Sergei E. 1930: Sitātapatrā-dhāran̄ī v uigurskoi redaktsii [An Uyghur version of Sitātapatrā-dhāranīi]. Doklady Akademii nauk SSSR. Seriia "B" [Reports of the Academy of Sciences of the USSR. "B" Series] 5. Moscow: Izdatel'stvo Akademii nauk SSSR: 88-94.

MaLOv, Sergei E. 1932: "Uigurskie rukopisnye dokumenty ekspeditsii S.F. Ol'denburga" [Uyghur manuscript documents of S.F. Oldenburg's expedition]. Zapiski Instituta vostokovedeniia Akademii nauk SSSR [Transactions of the Institute of Oriental Studies of the Academy of Sciences of the USSR]. Leningrad: Izdatel'stvo Akademii nauk SSSR: 129-149.

Malov, Sergei E. 1951: Pamiatniki drevnetiurkskoi pis'mennosti. Teksty i issledovaniia [Monuments in Old Turkic script. Texts and studies]. Moscow, Leningrad: Izdatel'stvo Akademii nauk SSSR.

OldennURG, Sergei F. 1914: Russkaia Turkestanskaia ekspeditsiia 1909 goda. Kratkii predvaritel'nyi otchet [Russian Turkestan Expedition of 1909. A brief preliminary report]. St. Petersburg: Idatel'stvo Imperatorskoi Akademii Nauk.

Oldenburg, Sergei F. 1917: "Ekspeditsiia D.A. Klementsa v Turfan v 1898 godu" [D.A. Klementz's Expedition to Turfan in 1898]. Izvestiia Vostochno-Sibirskogo otdela Imperatorskogo Russkogo Geograficheskogo Obshchestva [Proceedings of the East Siberian Branch of the Imperial Russian Geographical Society]. Vyp. 45. Irkutsk: Tipografiia Irkutskogo Tovarishchestva Pechatnogo Dela: 219-231.

Pamiatka 1920: Aziatskii Muzei Rossiiskoi Akademii Nauk. 1818-1918. Kratkaia pamiatka. [The Asiatic Museum of the Russian Academy of Sciences. 1818-1918. Summary]. St. Petersburg: Rosskiiskaia Gosudarstvennaia Akademicheskaia Tipografiia.

PANG, Tatiana A. 2018: Man'chzhurskii fond [Manchu Collection]. Aziatskii Muzei - Institut vostochnikh rukopisei. Putevoditel' [Asiatic Museum - Institute of Oriental Manuscripts, RAS. Guidebook]. Moskva: Izdatel'stvo vostochnoi literatury: 270-293.

Popova, Irina F. 2008: "Russian Expeditions to Central Asia at the Turn of the 20th Century". In: Russian Expeditions to Central Asia at the Turn of the 20th Century. Collected articles. Ed. by Irina F. Popova. St. Petersburg: Slavia Publishers: 11-39.

PoPova, Irina F. 2011: "Turfanskaia kollektsiia A.I. Kokhanovskogo v sobranii IVR RAN" [The Turfan collection of A.I. Kokhanovskii kept in the IOM, RAS]. In: V potoke nauchnogo tvorchestva. K 80-letiiu V.S. Miasnikova [In the stream of academic creativity. Festschrift to the 80th birth anniversary of academician V.S. Miasnikov]. Moscow: Nauka: 161-166.

RADLOFF, Wilhelm 1899: Altuigurische Sprachproben aus Turfan. Nachrichten über die von der Kaizerlichen Akademie der Wissenschaften zu St. Petersburg im Jahre 1898 ausgerüstete Expedition nach Turfan. Hf. 1. St. Petersburg: Izdatel'stvo Akademii Nauk: 55-83.

Radloff, Wilhelm 1909: Chuastuanit, das Bussgebet der Manichäer. Herausgegeben und überzetzi von W. Radloff. St. Petersburg: Buchdruckerei der Kaiserlichen Akademie der Wissenschaften. 
RadLofF, Wilhelm 1910: Tišastvustik: ein in Türkischer Sprache bearbeitetes Buddhistisches Sūtra. I. Transcription und Übersetzung von W. Radloff. II. Bemerkungen zu den Brāhmīglossen des Tišastvustik-Manuscripts (Mus. As. Kr. VII) von Baron A. von StaëlHolstein. Bibliotheca Buddhica XII. St. Pétersbourg.

Radloff, Wilhelm 1911: Kuan-ši-im Pusar. Eine türkische Übersetzung des XXV. Kapitels der chinesischen Ausgabe des Saddharmapundarīka. Hrsg. und übersetzt von W. Radloff. Bibliotheca Buddhica XIV. St. Pétersbourg: l'Académie Impériale des Sciences.

Radloff, Wilhelm \& Malov, Sergei 1930: Suvarṇaprabhāsa (Sutra Zolotogo Bleska). Tekst uigurskoi redaktsii. Izdali V.V. Radlov i S.E. Malov [Suvarṇaprabhāsa (The Sūtra of Golden Light). The text of Uyghur Version. Ed. by Wilhelm W. Radloff and Sergei E. Malov]. Bibliotheca Buddhica XVII. St. Petersburg: Typographiia of the Imperial Academy of Sciences.

RoвorovsкII, Vsevolod I. 1900: Trudy ekspeditsii Imperatorskogo Geograpficheskogo obshchestva po Tsentralnoi Azii. Part 1. Otchet nachal'nika ekspeditsii V.I. Roborovskogo [Records on the Expedition to Central Asia organized by the IRGS. Part 1: Report of expedition leader V.I. Roborovskii]. St. Petersburg: Tipografiia M.M. Stasiulevicha.

RoвorovskiI, Vsevolod I. 1949: Puteshestvie v Vostochnii Tian'-Shan' i v Nan'-Shan'. Moscow: Nauka.

Salemann, Carl 1908: Specifiertes Verzeichnis der literrarischen Fragmente in der Krotkov'schen Samlung. Sept. 1908. Serindica. Spiski uigurskikh kollektsii Aziatskogo Muzeia [Lists of the Uyghur collections of the Asiatic Museum]. 1918. The Archives of the Department of Manuscripts and Documents of the IOM, RAS. Access number - Apx. 69.

StCHERBATSKY, Fyodor I. 1935: "S.F. Ol'denburg kak indianist" [S.F. Oldenburg as Indologist]. Zapiski AN SSR. Vyp. 4 [Transactions of the IOS, USSR RAS. Issue 4]. Moscow, Leningrad: Nauka: $15-23$.

SuK 1993: Yamada Nobuo. Sammlung Uigurischer Kontrakte = Uiguru-bun keiyaku monjo shūsei ウイグル文契約文書集成. Hrsg. von Juteb Oda, Peter Zieme, Hiroshi Umemura, Takao Moriyasu. (Bd. 1: Gesammelte Arbeiten über die uigurischen Dokumente von N. Yamada. Bd. 2: Textband. Bd. 3: Faksimileband). Osaka: Osaka University Press.

Tugusheva, Lilia Yu. 1971: "Three Letters of Uighur Princes from the MS Collection of the Leningrad Branch of the Institute of Oriental Studies". Acta Orientalia, XXIV/2. Budapest: Academiae Scientiarum Hungaricae: 173-187.

Tugusheva, Lilia Yu. 1996: "Ein Fragment eines frühmittelalterlichen uigurischen Textes". In: Turfan, Khotan und Dunhuang. Berlin: Akademie Verlag: 353-359.

Tugusheva, Lilia Yu. 1970: "Drevnie uigurskie stikhi (rukopis' iz sobraniia Leningradskogo otdeleniia Instituta vostokovedeniia AN SSSR)" [Old Uyghur verses (manuscript from the collection of the Leningrad Branch of the Institute of Oriental Studies of the Academy of Sciences of the USSR)]. Sovetskaia tiurkologiia [Soviet Turkology], 1970/2: 102-106.

TuguSHEVA, Lilia Yu. 1972: “Uigurskaia rukopis' iz sobraniia LO IVAN SSSR” [Uyghur manuscript from the collection of Leningrad Branch of the Institute of Oriental Manuscripts of the Academy of Sciences of the USSR]. Pis'mennye pamiatniki Vostoka. Istoriko-filologicheskie issledovaniia. Ezhegodnik 1969 [Written monuments of the Orient. Studies on History and Philology. Annual 1969]. Moscow: Nauka, Glavnaia redaktsiia vostochnoi literatury: 315339.

Tugusheva, Lilia Yu. 1975: "Dva uigurskikh dokumenta iz rukopisnogo sobraniia Leningradskogo Otdeleniia Instituta Vostokovedeniia Akademii Nauk SSSR" [Two Uyghur documents 
from the manuscript collection of the Leningrad Branch of the Institute of Oriental Studies of the Academy of Sciences of the USSR]. Sovetskaia tiurkologiia [Soviet Turkology] 1975/4: 92-101.

TugusheVA, Lilia Yu. 1978: "Dva kolofona iz sobraniia drevneuigurskikh rukopisei LO IVAN SSSR" [Two colophones from the Old Turkic manuscript collection of the Leningrad Branch of the Institute of Oriental Studies of the Academy of Sciences of the USSR]. Tiurkologicheskii sbornik [Collected articles on Turkic studies] 1975. Moscow: Nauka, Glavnaia redaktsiia vostochnoi literatury: 252-261.

TugusheVA, Lilia Yu. 1991: Uigurskaia versiia biografii Siuan'-tszana (fragmenty iz leningradskogo rukopisnogo sobraniia Instituta vostokovedeniia AN SSSR) [Uyghur version of the Biography of Xuanzang (fragments from the manuscript collection of the Institute of Oriental Studies of the Academy of Sciences of the USSR]. Moscow: Nauka, Glavnaia redaktsiia vostochnoi literatury.

TugusheVA, Lilia Yu. 1996a: "Neskol'ko uigurskikh dokumentov iz rukopisnogo sobraniia Sankt-Peterburgskogo filiala IV RAN" [Several Uyghur documents from the manuscript collection of the St. Petersburg Branch of the Institute of Oriental Studies of the Russian Academy of Sciences]. Peterburgskoe vostokovedenie $=$ St. Petersburg Journal of Oriental Studies 8: 215-238.

Tugusheva, Lilia Yu. 1996b: "Early Medieval Uighur Records from East Turkestan". Мanuscripta Orientalia 2/3: 8-15.

Tugusheva, Lilia Yu. 2004: "A Fragment of a Draft of an Early Medieval Uighur Verse Text". Turfan Revisited. The First Century of Research into the Arts and Cultures of the Silk Road. Berlin: Dietrich Reimer Verlag: 355-357.

Tugusheva, Lilia Yu. 2007: "Fragmenty rannesrednevekovykh tiurkskikh gadatel'nykh knig iz rukopisnogo sobraniia Sankt-Peterburgskogo filiala Instituta vostokovedeniia RAN" [Fragments of early medieval Turkic fortune-telling books from the manuscript collection of St. Petersburg Branch of the Institute of Oriental Studies of the Russian Academy of Sciences]. Pis'mennye pamiatniki Vostoka 7: 37-46.

Tugusheva, Lilia Yu. 2008a: Khuastvanift (Manikheiskoe pokaianie v grekhakh) / Predislovie, transkriptsiia uigurskogo teksta, perevod L.Yu. Tugushevoi. Kommentarii A.L. Khosroeva. Faksimile teksta [Xuastvanift (Manichaean confession of sins). Facsimile Edition. Preface, transcription of the Uighur text, translation by L.Yu. Tugusheva. Comments by A.L. Khosroev]. St. Petersburg: Nestor-Istoriia.

Tugusheva, Lilia Yu. 2008b: Sutra Obshchiny belogo lotosa: tiurkskaia versiia. Transkriptsiia, perevod s rannesrednevekovogo tiurkskogo iazyka, predislovie, primechaniia, ukazatel' slov L.Yu. Tugushevoi [The Sutra of the White Lotus Society: Turkic version. Transcription, translation from the early medieval Turkic anguage, foreword, notes, word-index by L. Yu. Tugusheva]. Moscow: Vostochnaia literatura.

Tugusheva, Lilia Yu. 2008c: Expeditions to Central Asia and the Discovery of Early Medieval Turkic Manuscripts. Russian Expeditions to Central Asia at the Turn of the 20th Century. Collected articles. Ed. by I.F. Popova. St. Petersburg: Slavia Publishers: 40-49.

Tugusheva, Lilia Yu. 2013: Uigurskie delovye dokumenty X-XIV vv. iz Vostochnogo Turkestana. Predislovie, transkriptsiia, perevods drevneuigurskogo L.Yu. Tugushevoi; faksimile rukopisei [Uyghur official documents of the 10th-14th cc. from Eastern Turkestan. Foreword, transcription, translation from Old Uyghur by L.Yu. Tugusheva; facsimile of the manuscripts]. Moscow: Nauka, Vostochnaia literatura. 
USp 1928: Radlow Wilhelm. Uigurische Sprachdenkmäler. Materialien nach dem Tode des Verfassers mit Ergänzungen von S. Malov herausgegeben. Leningrad: Verlag der Akademie der Wissenschaften der USSR.

Whitfield, Susan 2008: Scholarly Respect in an Age of Political Rivalry. In: Russian Expeditions to Central Asia at the Turn of the 20th Century. Collected articles. Ed. by Irina F. Popova. St. Petersburg: Slavia Publishers: 203-218. 